\title{
Assigning Features and Experiences During the Physical Movement Control Conditions Throughout Pandemic COVID-19
}

\author{
Muhamad Firdaus Ramli \\ Chief Editor \\ Faculty of Arts, Computers and Creative Industries \\ Sultan Idris Education University \\ Tanjong Malim, Perak, Malaysia \\ firdaus.ramli@fskik.upsi.edu.my
}

To cite this article (APA): Ramli, M. F. (2020). Assigning Features and Experiences During the Physical Movement Control Conditions Throughout Pandemic COVID-19. KUPAS SENI: Jurnal Seni Dan Pendidikan Seni, 8(2), i-iv. https://doi.org/10.37134/kupasseni.vol8.2.editorial.2020

To link to this article: https://doi.org/10.37134/kupasseni.vol8.2.editorial.2020

\begin{abstract}
Article placement on session of Vol. 8 No. 2, (2020): KUPAS SENI: Jurnal Seni Dan Pendidikan Seni is composed of six (6) educational institutions from within Malaysia. Among the authors are from Faculty Art and Design, Universiti Teknologi Mara, Shah Alam, Selangor. Second institution is from the Faculty of Language and Communication, Universiti Pendidikan Sultan Idris, Tanjong Malim, Perak. Third institution is from the Sekolah Menengah Kebangsaan Penambang, Kota Bharu, Kelantan. Fourth institution is from the Fakulti Seni, Komputeran Dan Industri Kreatif, Universiti Pendidikan Sultan Idris, Tanjong Malim, Perak. Fifth institution is from the Sekolah Menengah Kebangsaan Entabuan P/S 277, Tenom, Sabah. Finally, institution is from the Fakulti Seni Gunaan dan Kreatif, Universiti Malaysia Sarawak, Sarawak.
\end{abstract}

Keyword: weapon, visual framing, pua sungkit, Non-PSV option Teachers, School landscape, Ngajat

\section{BACKGROUND}

The article that parted and meet for Vol. 8 No. 2, (2020) represents six (6) study topics namely as Symbolism of the Sabah Bugis Motive: Sign and Meaning: Weapon and Textile by Nordin and Che Cob (2020). The second (2) article is visual framing of Malaysia`s National Day Press advertisement in Utusan Melayu / Malaysia from 1957 to 2007 by Daud, Abd. Rahim and Che Cob (2020). The third (3) article is mentioned to The Iban's Community perceptions of Pua Sungkit Weaving at Batang Ai by Klinsing and Usop (2020). The fourth (4) article is Developing an Art Language Teaching Module to Increase Mastery of Non-Art Teachers Option in Form One by Jenal and Ramli (2020). The fifth article (5) is Effectiveness of Adapting the Concept of Cultural Identity in Landscape Design in School Grounds by Jukim, Mohd Noor and Zalay@Zali (2020). The final article is with respect to namely Ngajat Iban: A Cultural Study by Kiyai@Keai, Tugang and Seer (2020).

\section{ARTICLE DISTRIBUTION}

Nordin and Che Cob (2020) experienced insight on Symbolism of the Sabah Bugis Motive: Sign and Meaning: Weapon and Textile. Their research aims to explain the motive of the traditional Bugis symbol and interest in Tawau, Sabah (weapon \& textile). Their research is the representation of a descriptive qualitative approach with interviews, observation, documents and literature review. Data analysis procedures in this research are ethnography Clifford Geertz. The outcomes of their research designated that weapons and textiles have a philosophy and symbolic meaning of Bugis Sabah's motive. 
In their study, textile for Bugis Sabah has convinced symbolic meanings that are very dependent on the wearer for green colour for nobility women, red colour for teenager's girl, red colour for married women, purple colour for widows, black colour for elderly and white colour for assistants and shaman. Lippa Sabbe' cloth also has its significance and philosophy. The motifs found in this Lippa Sabbe 'is Balo Tettong, Mallobang, Cobo, Balo and Balo Renni. For weapons, the beneficial condition arrangement is also an influential viewpoint of a culture that has a thought in the lives of the community. These cultural preferences are an important and valuable aspect of one's personality. This is also because the importance of the culture is also a guideline that is significant sufficient for each human behaviour. In culture, there are approaches and values for them to learn.

Furthermore, Daud et al. (2020) shared about the visual framing of Malaysia's National Day Press advertisement in Utusan Melayu / Malaysia from 1957 to 2007. Press advertisement is one of the areas of graphic communication. Nevertheless, dedicated research on it has undergone limited attention from researchers. Their study discusses the use of press advertisement as a medium of communication to spread the message of the National Day Celebration in Malaysia. Their study using advertisements that appear in Utusan Melayu / Malaysia in August and September that commencing in 1957 until 2007. Their study using a qualitative study using the method of document analysis. The visual evaluations have to be applied in an interview with a specialist in advertising. The outcomes determine that there is a connection between the visual framing of the National Day proclamation with socioeconomic status, current political context and the diversity of religious and racial communities.

In addition, Klinsing and Usop (2020) shared about the Iban's Community perceptions of Pua Sungkit Weaving at Batang Ai. Their study aims to interpret the Iban community's understanding of pua sungkit weaving in Batang Ai. The three objectives of their study are to identify pua sungkit in the Batang Ai area. Moreover, examine the function of pua sungkit in the life of the Iban community and see the changes in the making of pua sungkit involving ten longhouses in Batang Ai, Lubok Antu. To achieve these objectives, researchers implement library search and field study by applying cultural and art theory. Cultural conjecture is disclosed to the traditions and daily activities performed. While the art theory reveals the heritage and handicrafts fabricated by the Iban community. The interview and questionnaire sessions conducted involved a determination of fifty (50) respondents and fourteen (14) informants in demonstrating the association between the making of pua sungkit and the culture of the Iban community. The interview concourse discovered that exceptional informants who were still healthy were willing to teach. On the other hand, the rest did not want to due to their age. The questionnaire session showed that the majority of respondents agreed that pua sungkit is a replacement for pua kumbu. The discoveries show that there are still numerous among the Iban community who are enthusiastic and skilled in weaving and fabricating pua sungkit. However, the young Iban women are presently attempting to discover to weave. In determination, the weaving heritage is still important and preserved because of the purposes of pua sungkit as a unique piece of traditional women's clothing. As a special fabric, the used in religious ritual ceremonies, as a wedding gift and as a decorative item at home.

Moreover, Jenal and Ramli (2020) have shared issues of developing an Art Language Teaching Module to Increase Mastery of Non-Art Teachers Option in Form One. Their study aims to develop a Visual Arts Language Module (BSV) for non-optional Visual Arts Education teachers who practice inform one (1) at school. Their study utilises the model design adapted by Module Sidek and Model Dick and Reiser as the main policies. The case study involved three (3) respondents who are not secondary school art education options nearby Kota Bharu, Kelantan who have been selected to recognise teaching and facilitation difficulties as well as the needs of the BSV Module in Visual Arts Language. Meanwhile, the sample limit of thirty (30) students from the same three (3) schools are involved in the implementation of this BSV module. The effectiveness of the BSV Module as a teaching and accommodating property is analyzed and measured qualitatively between teachers and students through questionnaires. The observations and interviews especially those that are emotional, motivational and empathic (understanding others) related to people, certain groups or tangible circumstances (Chua, 2006).

Therefore, Jukim et al. (2020) have shared issues on the effectiveness of Adapting the Concept of Cultural Identity in Landscape Design on School Grounds. Their study aims to classify the effectiveness of compliance of the concept of local cultural identity in school landscape design. This is because landscape range is the totality of the potential elements to form a school environment conducive 
to teaching and learning. The objective of their study is to demonstrate the concept of local cultural identity to be adapted to the school landscape space. Moreover, they evaluate the effectiveness of cultural identity adaptation in landscape design. Their study was conducted descriptively using qualitative approaches involving case studies in a school. Their study involved twenty (20) participants including five (5) teachers, five (5) community members and ten (10) students. Data were obtained during field studies using observational and interview methods. Data were analyzed manually through documentation of the landscape development manner. Next, the data were categorized according to the themes that have been developed according to the objectives of the study. Their findings show that the adaptation of the concept of cultural identity in developing the landscape in the school gives a new thought to the design of the school landscape.

Subsequently, Kiyai@Keai et al. (2020) have shared about the Ngajat Iban as a cultural study. The Ngajat is a traditional dance which synonym with the ethnic of Iban in Sarawak. This dance is regularly performed in festive such as the Gawai Dayak and matrimony. The determination of the dance is to inspire and present appreciation for the attended guest. In Iban's culture, the Ngajat dance can be classified into two (2) sections by indicating gender which is Ngajat Indu (Female's dance) and Ngajat Laki (Male's dance). Other than that, the Ngajat dance has significant meaning and sacred in the Iban's experience depending on the routine performed by the ethnic itself. Therefore, this is an ethnographic knowledge that emphasized the intangible culture of the Iban's Ngajat. Their study practised the qualitative method of exploratory research and exploring a concept of phenomena through conducting fieldwork and interview with a specialist in Iban's culture.

\section{CONCLUSION}

In a way, Nordin and Che Cob (2020) have further stressed for knowing the elements such as Pamor Polobessi functions to providing content on the values of heroism as arowaenengeng. Meanwhile, abbaramparengeng is meant to be wealth and the authority known as arajangeng is placed in Polobessi. According to Daud et al. (2020) further shared about the indications of their study have provided a supplementary discovery. Their documentation is a reference to the creative arts and design community and society. On the other hand, Klinsing and Usop (2020) mention the implication is that there is a proposition to construct a weaving training centre to build a website as a marketing platform for the local pua sungkit weaving. A single of the elective subjects in schools is to conserve and deliver the weaving educational heritage. Furthermore, Jenal and Ramli (2020) shared period quantitative methods employing pre and post-tests are carried out to determine that student accomplishment is further significant in the assessment of Classroom Mastery Level (TP). The comprehension inquiry (formative) compared to achievement before the use of Module BSV. In addition, following Jukim et al. (2020), their collaboration between teachers and participants in their study successfully adapted replicas of kulundi musical instruments and shields in the school landscape space. In conclusion, their study can provide guidance to teachers and the community to design a landscape with the concept of local cultural identity. Conclusively, Kiyai@Keai et al. (2020) have manifested study sites are located in Betong and Sri Aman which have the largest Iban's settlement in Sarawak, Malaysia. Their studies find the Ngajat dance still widely practised and there is an attempt to conserve the traditional dance to prevent it from extinction.

\section{REFERENCES}

Daud, E., Abd. Rahim, R., \& Che Cob, S. A. (2020). The visual framing of Malaysia`s National Day Press advertisement in Utusan Melayu / Malaysia from 1957 to 2007. KUPAS SENI: Jurnal Seni Dan Pendidikan Seni, 8(2), 13-20. https://doi.org/10.37134/kupasseni.vol8.2.2.2020

Jenal, D., \& Ramli, H. (2020). Developing an Art Language Teaching Module to Increase Mastery of Non-Art Teachers Option in Form One. KUPAS SENI: Jurnal Seni Dan Pendidikan Seni, 8(2), 44-51. https://doi.org/10.37134/kupasseni.vol8.2.4.2020 
Jukim, H., Mohd Noor, A. I., \& Zalay@Zali, A. A. (2020). Effectiveness of Adapting the Concept of Cultural Identity in Landscape Design in School Grounds. KUPAS SENI: Jurnal Seni Dan Pendidikan Seni, 8(2), 52-69. https://doi.org/10.37134/kupasseni.vol8.2.5.2020

Kiyai@ Keai, G., Tugang, N., \& Seer, O. (2020). Ngajat Iban: A Cultural Study. KUPAS SENI: Jurnal Seni Dan Pendidikan Seni, 8(2), 70-83. https://doi.org/10.37134/kupasseni.vol8.2.6.2020

Klinsing, J., \& Usop, C. (2020). The Iban's Community perceptions of Pua Sungkit Weaving at Batang Ai. KUPAS SENI: Jurnal Seni Dan Pendidikan Seni,8(2), 21-43. https://doi.org/10.37134/kupasseni.vol8.2.3.2020

Nordin, M. A., \& Che Cob, S. A. (2020). Symbolism of The Sabah Bugis Motive: Sign and Meaning: Weapon and Textile. KUPAS SENI: Jurnal Seni Dan Pendidikan Seni, 8(2), 1-12. https://doi.org/10.37134/kupasseni.vol8.2.1.2020 